\title{
Effect of Xylitol Chewing Gum on Presence of Streptococcus mutans in Saliva
}

\author{
Nguyen Thi Hong Minh ${ }^{1}$ (D) Le Hai ${ }^{2,3 *}$ (D) Tran Thi Nga Lien $^{1}$ (D), Tran Cao Binh ${ }^{1}$ (D) \\ ${ }^{1}$ Department of Periodontology, National Hospital of Odonto-Stomatology, Hanoi, Vietnam; ${ }^{2}$ Department of Poly-Clinical, 108 \\ Military Central Hospital, Hanoi, Vietnam; ${ }^{3}$ Faculty of Odonto-Stomatology, 108 Institute of Clinical Medical and Pharmaceutical \\ Sciences, Hanoi, Vietnam
}

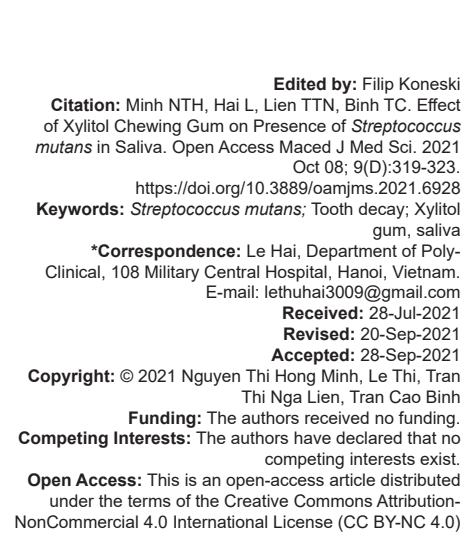

\section{Background}

According to the World Health Organization (WHO), oral disease ranks third among the other serious diseases in the world, after cancer and cardiovascular disease [1]. Results of the National Oral Health Survey conducted in 2019 by Hanoi Central Dental Hospital showed that about $90 \%$ of the Vietnamese population suffered from dental and oral diseases, of which the most common were decay and gingival inflammation around the teeth [2]. Tooth decay not only affects the health of the patient but in the future may lead to costly treatment options. Many research programs as well as recommendations aimed at preventing tooth decay have been implemented by the World Health Organization over the years [3], [4], [5]. Although the rate of decay in the community has decreased significantly, it is still high and requires better preventive measures to meet the goals set by the World Health Organization.

Previously, conducted research has shown that the bacteria in the dental plaque break down sugars, causing formation of acid that causes destruction and forms cavities in the teeth. Among these bacteria, the role of Streptococus mutans (Streptococus) in tooth decay pathogenesis is emphasized. For instance, it was reported to have a direct relationship with tooth decay. According to previous studies, the higher the presence of Streptococus mutans in the oral cavity is, the more likely the tooth decay might be to occur [6], [7], [8], [9].

Creating good oral hygiene habits such as brushing the teeth with fluoride toothpaste, eating a healthy diet is another simple way to prevent dental diseases. Research has shown that xylitol is an effective sugar alternative [10], [11]. Xylitol is as sweet as sucrose but is only provides $1 / 3$ of the calories and is found naturally within various fruits, vegetables, and from the bark of the Bulo tree [12].

Previously, conducted studies have shown that xylitol when used as a sweetener in chewing gum has a beneficial effect in reducing the amount of $S$. mutans bacteria in the mouth and helps reduce the incidence of the tooth decay [13], [14], [15]. However, in Vietnam, the total number of studies has been conducted on effect of xylitol on tooth decay. Therefore, the aim of 
the study is to evaluate the effectiveness of using xylitol gum on the $S$. mutans present in the saliva.

\section{Materials and Methods}

\section{Study design and select research subjects}

The study design was a clinical study conducted at the Hanvinco Texture Factory (Hanoi). The study design is shown in Figure 1. The factory workers were interviewed and examined for eligibility for inclusion in the study.

\begin{tabular}{|c|}
\hline Volunteers $(\mathrm{n}=254)$ \\
\hline Selection criterias \\
\hline Oral hygient instruction and brushing twice daily in two weeks \\
\hline Quantification of S. mutans in saliva \\
\hline Applicants (having S.mutans level in saliva $\left.\geq 10^{4} \mathrm{CFU} / 1 \mathrm{ml}\right) \mathrm{n}=80$ \\
\hline Informed consent signing \\
\hline Received $4.8 \mathrm{~g}$ xylitol per day in 4 weeks \\
\hline Quantification of S.mutans in saliva $(\mathrm{n}=80)$ \\
Analysed ( $\mathrm{n}=80)$ \\
\hline
\end{tabular}

Figure 1: Flowchart of study design

Inclusion criteria were: The presence of at least 24 teeth, including at least 20 teeth without presence of caries on tooth, V-type cavity, more tartar or progressive periodontitis (that affected to effectiveness of Xylitol in oral bacterium). Participants were excluded if they were diagnosed with systemic diseases or were unable to follow the study protocol.

After selective examination, 254 subjects between the ages of 18 and 63 were included in the clinical trial. Study subjects included 50 men (accounting for 19.7\%) and 204 women (accounting for $80.3 \%$ ) all following normal oral hygient regime. The saliva samples were taken to quantify the levels of S. mutans in saliva. The demographic characteristics of the participants are shown in Table 1.

Table 1: Demographic characteristics of participants

\begin{tabular}{ll}
\hline Parameters & Values \\
\hline Age & 37,87 \\
Mean age & $18-63$ \\
Range age & \\
Sex: & $50(19.7 \%)$ \\
Male & $204(80-3 \%)$ \\
Female & \\
\hline
\end{tabular}

All 254 participants received oral hygiene instructions, and received standard toothpaste and toothbrush. These participants brushed their teeth for 2 weeks before providing a saliva sample for S. mutans. The 80 subjects, $70(87.5 \%)$ males and ten females $(12.5 \%)$, with the highest number of salivary S. mutans were recruited for the further analysis.

\section{Clinical intervention methods}

The study used Lotte xylitol chewing gum with a content of $0.6 \mathrm{~g}$ xylitol sweetener circulated in Vietnam under License No. 307/2015/YTBD-XNCB. Each clinical intervention participant strictly followed the intervention protocol as follows: Chewed Lotte xylitol gum after each meal, two tablets each time (at work under the supervision of research collaborators) and 1 time in the evening (total 4 times/day), continuously for 4 weeks. It was chewed for no more than 5 min and the participants were instructed not to brush their teeth for at least $1 \mathrm{~h}$ after chewing. This xylitol intake has been recommended in the previous studies by Abdelwahab et al. [16] and Ribelles Llop et al. [17]. Participants were advised to not have any other chewing gum at the same time and to follow oral hygiene protocol using toothbrush and toothpaste. After 4 weeks, saliva samples of these subjects were collected spontaneously (non-stimulated saliva) into eppendorf tubes containing sterile physiological saline and transferred to laboratory within 1 hour for storage and preparation of quantitative tests.

\section{S. mutans}

\section{Sampling saliva and quantification of}

Participants were instructed not to swallow their saliva for $1 \mathrm{~min}$ and then split out non-stimulating saliva into a sterile graduated test tube. Participants were asked to give $1 \mathrm{ml}$ of saliva. All saliva samples were stored in a cold storage box at $4^{\circ} \mathrm{C}$ and then transferred to the lab for microbiological testing.

Saliva samples were quantified containing S. mutans by real-time PCR method at Central Laboratory, Central Hospital for Tropical Diseases of Vietnam, following the three-step process: DNA extraction (Using QIAamp DNA Mini Kit from Qiagen Company), Real-time PCR implementation (using the genesig gene Standard Kit Streptococcus mutans from Primerdesign) and the results were evaluated.

As the standard curve of this real-time PCR method was linear for samples containing from $10^{4}$ cells to $10^{8}$ cells per $\mathrm{ml}$, only samples containing at least $10^{4}$ cells $/ \mathrm{ml}$ were used for analysis before and followed after intervention.

\section{Statistical analysis}

For statistical analysis, software SPSS version 11.5 (IBM, Chicago) was used for data 
analysis. The normality of the data was analyzed using Anderson-Darling normality test. The changes in S. mutans counts were compared using a paired t test and Wilcoxon-Signed Ranks test. Mc Nemar test and Chi-square test were used to compare the differences between $S$. mutans counts before and followed intervention. Statistical significance was established at $p<0.05$.

\section{Ethics approval}

The study was conducted in accordance with the ethical principles for clinical research described in the Declaration of Helsinki. The study protocol was approved by the Scientific and Ethical committee of the National Hospital of Odonto-Stomatology, Hanoi, Vietnam (no. 314/QD-TCCB signed May 30, 2018). The study took place at the National Hospital of Odonto-Stomatology from June 2018 to October 2018 in accordance with CONSORT guidelines for clinical trials. All participants of the study signed an informed consent form.

\section{Results and Discussion}

Quantitative results of $S$. mutans bacteria in saliva of 254 subjects showed that over $50 \%$ of subjects had no or too little S. mutans; $1.2 \%$ of subjects with S. mutans quantity below $10^{4} \mathrm{CFU} / \mathrm{ml}$ of saliva; $26 \%$ of subjects had S. mutans quantity of $10^{4}-10^{5} \mathrm{CFU} / \mathrm{ml}$ of saliva, the rest had S. mutans quantity of over $10^{5} \mathrm{CFU} / \mathrm{ml}$ of saliva $(19.7 \%)$. This result shows that nearly $20 \%$ of the subjects examined had a high risk of tooth decay. For subjects in saliva, in addition to normal oral hygiene measures, additional oral care measures are required to prevent tooth decay (Table 2).

Table 2: Quantitative results of $S$. mutans bacteria in saliva of 254 subjects

\begin{tabular}{|c|c|c|c|c|c|c|c|}
\hline \multicolumn{2}{|c|}{ None } & \multicolumn{2}{|c|}{$<10^{4} \mathrm{CFU} / \mathrm{ml}$} & \multicolumn{2}{|c|}{$10^{4-} 10^{5} \mathrm{CFU} / \mathrm{ml}$} & \multicolumn{2}{|c|}{$\geq 10^{5} \mathrm{CFU} / \mathrm{ml}$} \\
\hline $\mathrm{N}$ & $\%$ & $\mathrm{~N}$ & $\%$ & $\mathrm{~N}$ & $\%$ & $\mathrm{~N}$ & $\%$ \\
\hline 135 & 53.1 & 3 & 1.2 & 66 & 26.0 & 50 & 19.7 \\
\hline
\end{tabular}

Of the 80 participants included in the further studies, $57.5 \%$ initially had a $S$. mutans quantity of $10^{4}-10^{5} \mathrm{CFU} / \mathrm{ml}$ of saliva; the rest of the $S$. mutans quantity exceeded $10^{5} \mathrm{CFU} / \mathrm{ml}$ of saliva (Table 3 ).

Table 3: Saliva levels of S. mutans in participants using xylitol gum at baseline

\begin{tabular}{|c|c|c|c|c|c|c|}
\hline & \multicolumn{2}{|c|}{$10^{4}-10^{5} \mathrm{CFU} / \mathrm{ml}$} & \multicolumn{2}{|c|}{$\geq 10^{5} \mathrm{CFU} / \mathrm{ml}$} & \multicolumn{2}{|c|}{ Total } \\
\hline & $\mathrm{N}$ & $\%$ & $\mathrm{n}$ & $\%$ & $\mathrm{~N}$ & $\%$ \\
\hline Male & 7 & 70.0 & 3 & 30.0 & 10 & 100.0 \\
\hline Female & 39 & 55.7 & 31 & 44.3 & 70 & 100.0 \\
\hline Total & 46 & 57.5 & 34 & 42.5 & 80 & 100.0 \\
\hline
\end{tabular}

After 4 weeks of using xylitol chewing gum, the number of participants having the number of $S$. mutans
Table 4: Saliva S.mutans level in participants using xylitol gum at 4 weeks

\begin{tabular}{|c|c|c|c|c|c|c|c|c|c|c|}
\hline & \multicolumn{2}{|c|}{ None } & \multicolumn{2}{|c|}{$<10^{4} \mathrm{CFU} / \mathrm{ml}$} & \multicolumn{2}{|c|}{$10^{4}-10^{5} \mathrm{CFU} / \mathrm{ml}$} & \multicolumn{2}{|c|}{$\geq 10^{5} \mathrm{CFU} / \mathrm{ml}$} & \multicolumn{2}{|c|}{ Total } \\
\hline & $\mathrm{N}$ & $\%$ & $\mathrm{n}$ & $\%$ & $\mathrm{~N}$ & $\%$ & $\mathrm{~N}$ & $\%$ & $\mathrm{~N}$ & $\%$ \\
\hline Male & 4 & 40.0 & 0 & 0.0 & 4 & 40.0 & 2 & 20.0 & 10 & 100.0 \\
\hline Female & 16 & 22.9 & 1 & 1.3 & 35 & 43.3 & 24 & 31.4 & 70 & 100.0 \\
\hline Total & 20 & 25.0 & 1 & 1.3 & 35 & 43.8 & 24 & 30.0 & 80 & 100.0 \\
\hline
\end{tabular}

more than $10^{5} \mathrm{CFU} / \mathrm{ml}$ of saliva showed a reduction in levels from $42.5 \%$ to $30 \%$, and $25 \%$ participants had no or too little S. mutans (Table 4). Thus, in our study, after using xylitol gum continuously 4 times/day for 4 weeks, the study results showed a decrease in the amount of S. mutans in the saliva of participants and the difference is statistically significant with $p<0.001$. Our result is similar to the results of previously conducted studies such as the study of Ribelles Llop et al. [17].

Bacteria that can ferment sugars into lactic acid that exist in the oral cavity are considered to cause tooth decay. They mainly belong to three groups of microorganisms: Streptococcus (Streptococcus mutans, Streptococcus sorbrinus, Streptococcus salivarius, Streptococcus milleri etc.), Lactobacillus (Lactobacillus acidophilus, Lactobacillus casei etc.), and Actinomyces. Among these bacteria, S. mutans is always found in human saliva, plaque, and in very high numbers in tooth decay areas [18], [19].

S. mutans is considered the main cause of tooth decay as this bacterium has strong acidogenicity (ability to produce acid), good acid resistance, and the ability to create extracellular and intracellular polysaccharide, the main component of dental plaque. S. mutans has been isolated in saliva, plaque, and in cavities. The presence of S. mutans has also been associated with the progression of tooth decay, which gets reduced or lost in the absence of S. mutans [20], [21], [22]. On the other hand, being infected of $S$. mutans in experimental animals caused tooth decay in these animals. Therefore, measures to reduce S.mutans bacteria in the oral environment are necessary to reduce the risk of tooth decay [23].

Studies conducted under different conditions have shown that the use of xylitol effectively reduced tooth decay significantly in the high-risk group (with a high incidence of cavities, nutrition, and hygiene. poor mouth) as well as the low-risk group (with a low incidence of cavities, using all of the present preventive measures) [24], [25], [26]. Until now, sugar-free chewing gum using the main sweetener, xylitol, has been certified by many dental associations around the world.

Research evidence shows that $S$. mutans was xylitol target tissue in in vivo studies; $S$. mutans was reduced or low in studies with prolonged use of $x X y$ litol as well as when use was discontinued; use of xylitol has the effect of reducing plaque accumulation; pregnant and lactating mothers using xylitol has the potential to reduce the risk of transmitting Streptococus mutans from mother to child; xylitol reduces the incidence of tooth decay in children [27], [28], [29]. 
Subjects with S.mutans in saliva above $10^{5} \mathrm{CFU} / \mathrm{ml}$ were considered to be at high-risk of tooth decay. In this study, up to $42.5 \%$ of the intervention research subjects belong to this group. The study results showed that, after using Lotte xylitol gum continuously 4 times/day for 4 weeks, the number of subjects with high amount of S.mutans in saliva was statistically significantly $(<0.05)$ decreased (Table 5$)$.

Table 5: Changes in percentage of volunteers having high level of saliva S.mutans $(\geq 105 \mathrm{VK} / \mathrm{ml})$ at baseline and 4 weeks

\begin{tabular}{llll}
\hline & $<10^{5} \mathrm{CFU} / \mathrm{ml}$ & $\geq 10^{5} \mathrm{CFU} / \mathrm{ml}$ & Total \\
\hline Baseline & $46(57.5 \%)$ & $34(42.5 \%)$ & 80 \\
At 4 weeks & $56(70 \%)$ & $24(30 \%)$ & 80 \\
$\mathrm{P}$ & & $<0.05^{*}$ & \\
\hline
\end{tabular}

${ }^{*}$ Mc Nemar Test, Chi-Square test.

\section{Conclusions}

Clinical study on 80 adults showed that using Lotte xylitol gum containing $4.8 \mathrm{~g}$ of xylitol, used 4 times/day, was effective in reducing the number of S.mutans bacteria in saliva when used daily in combination with tooth brushing.

\section{References}

1. Petersen PE. Global policy for improvement of oral health in the $21^{\text {st }}$ century-implications to oral health research of World Health Assembly 2007, World Health Organization. Community Dent Oral Epidemiol. 2009;37(1):1-8. https://doi. org/10.1111/j.1600-0528.2008.00448.x

PMid:19046331

2. Hải TĐ, Minh NT, Binh TC. National Oral Health Survey of Vienam. India: Medical Publishing House; 2019.

3. Gadiyar A, Gaunkar R, Kamat AK, Tiwari A, Kumar A. Impact of oral health-related behaviors on dental caries among children with special health-care needs in Goa: A cross-sectional study. J Indian Soc Pedod Prev Dent. 2018;36(1):33-7. https://doi. org/0.4103/jisppd.jisppd_214_17 PMid:29607836

4. Taqi M, Razak IA, Ab-Murat N. Comparing dental caries status using modified international caries detection and assessment system (ICDAS) and World Health Organization (WHO) indices among school children of Bhakkar, Pakistan. J Pak Med Assoc. 2019;69(7):950-4.

PMid:31308560

5. Ghasemianpour M, Bakhshandeh S, Shirvani A, Emadi N, Samadzadeh $\mathrm{H}$, Moosavi Fatemi $\mathrm{N}$, et al. Dental caries experience and socio-economic status among Iranian children: A multilevel analysis. BMC Public Health. 2019;19(1):1569. https://doi.org/10.1186/s12889-019-7693-1

PMid:31775741

6. Fejerskov $\mathrm{O}$. Changing paradigms in concepts on dental caries: Consequences for oral health care. Caries Res. 2004;38(3):182-191. https://doi.org/10.1159/000077753 PMid: 15153687
7. Gao X, Jiang S, Koh D, Hsu CY. Salivary biomarkers for dental caries. Periodontol 2000. 2016;70(1):128-41. https://doi. org/10.1111/prd.12100 PMid:26662487

8. Struzycka I. The oral microbiome in dental caries. Pol J Microbiol. 2014;63(2):127-35.

PMid:25115106

9. Fakhruddin KS, Ngo HC, Samaranayake LP. Cariogenic microbiome and microbiota of the early primary dentition: A contemporary overview. Oral Dis. 2019;25(4):982-95. https:// doi.org/10.1111/odi.12932

PMid:29969843

10. Cocco F, Carta G, Cagetti MG, Strohmenger L, Lingström $P$, Campus $G$. The caries preventive effect of 1-year use of low-dose xylitol chewing gum. Arandomized placebo-controlled clinical trial in high-caries-risk adults. Clin Oral Investig. 2017;21(9):273340. https://doi.org/10.1007/s00784-017-2075-5

PMid:28303470

11. Watthanasaen $S$, Merchant AT, Luengpailin $S$, Chansamak $N$, Pisek A, Pitiphat W. Xylitol-containing chewing gum for caries prevention in students with disabilities: A randomised trial. Oral Health Prev Dent. 2017;15(6):519-27. https://doi.org/10.3290/j. ohpd.a39668

PMid:29319061

12. Toors FA. Chewing gum and dental health. Literature review. Rev Belge Med Dent (1984). 1992;47(3):67-92.

PMid:1305985

13. Aluckal E, Ankola AV. Effectiveness of xylitol and polyol chewing gum on salivary streptococcus mutans in children: A randomized controlled trial. Indian J Dent Res. 2018;29(4):445-9. https://doi. org/10.4103/ijdr.ijdr_307_16

PMid:30127194

14. Shinde MR, Winnier J. Comparative evaluation of Stevia and Xylitol chewing gum on salivary Streptococcus mutans count-a pilot study. J Clin Exp Dent. 2020;12(6):e568-573. https://doi. org/10.4317\%2Fjced.55720

PMid:32665816

15. Akgül Ö, Ak AT, Zorlu S, Özdaş DO, Uslu M, Çayirgan D. Effects of short-term xylitol chewing gum on pro-inflammatory cytokines and Streptococcus mutans: A randomised, placebo-controlled trial. Int J Clin Pract. 2020;74(9):e13623. https://doi.org/10.1111/ijcp.13623 PMid:32729244

16. Abdelwahab DH, Allam GG, AzizAM. Effect of Xylitol and sugar-free chewing gums on salivary bacterial count of Streptococcus mutans and Lactobacilli in a group of Egyptian school children of different ages: A randomized clinical trial. Futur Dent J. 2018;4:216-20.

17. Llop MR, Jimeno FG, Acién RM, Dalmau LJ. Effects of xylito chewing gum on salivary flow rate, $\mathrm{pH}$, buffering capacity and presence of Streptococcus mutans in saliva. Eur J Paediatr Dent. 2010;11(1):9-14.

PMid:20359274

18. Mira A. Oral microbiome studies: Potential diagnostic and therapeutic implications. Adv Dent Res. 2018;29(1):71-7. https://doi.org/10.1177/0022034517737024 PMid:29355422

19. Valm AM. The structure of dental plaque microbial communities in the transition from health to dental caries and periodontal disease. J Mol Biol. 2019;431(16):2957-69. https://doi. org/10.1016/j.jmb.2019.05.016 PMid:31103772

20. Forssten SD, Björklund M, Ouwehand AC. Streptococcus mutans, caries and simulation models. Nutrients. 2010;2(3):290-8. https://doi.org/10.3390/nu2030290 PMid:22254021 
21. Klein MI, Hwang G, Santos PH, Campanella OH, Koo H. Streptococcus mutans-derived extracellular matrix in cariogenic oral biofilms. Front Cell Infect Microbiol. 2015;5:10. https://doi. org/10.3389/fcimb.2015.00010

\section{PMid:25763359}

22. Esberg A, Sheng N, Mårell L, Claesson R, Persson K, Borén T, et al. Streptococcus mutans adhesin biotypes that match and predict individual caries development. EBioMedicine. 2017;24:205-15. https://doi.org/10.1016/j.ebiom.2017.09.027 PMid:28958656

23. Bowen WH. Dental caries-not just holes in teeth! A perspective Mol Oral Microbiol. 2016;31(3):228-33. https://doi.org/10.1111/ omi.12132

PMid:26343264

24. Janakiram C, Deepan Kumar CV, Joseph J. Xylitol in preventing dental caries: A systematic review and metaanalyses. J Nat Sci Biol Med. 2017;8(1):16-21. https://doi. org/10.4103\%2F0976-9668.198344 PMid:28250669

25. Marghalani AA, Guinto E, Phan M, Dhar V, Tinanoff N Effectiveness of xylitol in reducing dental caries in children.
Pediatr Dent. 2017;39(2):103-10

PMid:28390459

26. Salli K, Lehtinen MJ, Tiihonen K, Ouwehand AC. Xylitol's health benefits beyond dental health: A comprehensive review. Nutrients. 2019;11(8):1813. https://doi.org/10.3390/nu11081813 PMid:31390800

27. Söderling EM. Xylitol, mutans streptococci, and dental plaque. Adv Dent Res. 2009;21(1):74-8. https://doi. org/10.1177/0895937409335642

PMid: 19717413

28. Baimbetov AK, Abzaliev KB, Jukenova AM, Bizhanov KA, Bairamov BA, Ualiyeva AY. The efficacy and safety of cryoballoon catheter ablation in patients with paroxysmal atrial fibrillation. Ir J Med Sci. 2021. https://doi.org/10.1007/s11845-021-02560-z

29. Baimbetov AK, Bizhanov KA, Abzaliyev KB, Bairamov BA, Yakupova IA. Prediction of arrhythmia recurrence after atrial fibrillation ablation in patients with normal anatomy of the left atrium. Int J Clin Pract. 2021;75(6):e14083. https://doi. org/10.1111/ijcp.14083

PMid:33555091 